\title{
Structure, distribution and taxonomic significance of leaf and petiole anatomical characters in five species of Terminalia (L.) (Combretaceae: Magnoliopsida)
}

\section{Opeyemi Philips Akinsulire*, Olaniran Temitope Oladipo, Akinwumi Johnson Akinloye and Herbert Chukwuma Illoh}

Obafemi Awolowo University. Department of Botany. Ile-Ife. Nigeria. Email: opeyemiakinsulire@gmail.com.

\begin{abstract}
This paper presents a synthesis of a comparative leaf anatomy (lamina and petiole) of five species of the genus Terminalia found in southwest Nigeria. Collections of plants were made from different locations in Southwest Nigeria as the geographic locations of the sites of collection were also georeferenced with a GPS device. The samples were identified at the Herbarium of Botany Department, Obafemi Awolowo University (Ife), Nigeria, and were subjected to anatomical examinations. Quantitative data were subjected to statistical analysis and the characters vary significantly $(\mathrm{P}=0.05)$. Anatomical characters which separate the taxa include petiole outline, epidermal features, vascular pattern, occurence of cortical and pericyclic fibres, presence/absence of, and types of trichomes etc, all found to be useful in identification of different species. The variations in the anatomical traits could be effectively used in taxonomic delimitation of the species and are helpful characters in determining the complexes in the genus such as adaptation of the species to xeric environments. The presence of 2-3 layers of palisade mesophyll cells in Terminalia mantaly, which is an adaptation of the species to drought, is diagnostic for the species. It is suggested that a comprehensive consideration of leaf lamina and petiole anatomy should be used as basis of taxonomy.
\end{abstract}

Keywords: Combretaceae; Diagnostic; Lamina; Petiole; Terminalia.
Received

June 5, 2018

Accepted

August 11, 2018

Released

August 31, 2018

Full Text Article

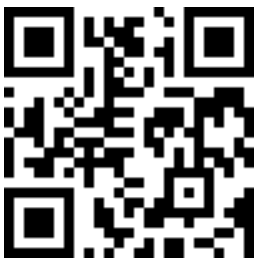

ORCID

구 0000-0001-8063-4908 Opeyemi Philips Akinsulire

(1) 0000-0003-2957-2961

Olaniran Temitope Oladipo

(ㄱ) 0000-0003-4256-862X Akinwumi Johnson Akinloye

(1) 0000-0003-1994-4012 Herbert Chukwuma Illoh 


\section{Introduction}

Terminalia, the second largest genus of the Family Combretaceae, derives its Latin name (Terminalis $=$ end) from position of the leaves, which are crowded at the ends of the shoots (Lamb and Ntima, 1971). The genus is a pantropical genus accommodating about 200 species (McGaw et al., 2001), and approximately fifty species of these are naturally distributed and native throughout eastern, southern and western Africa (Lebrun and Stork, 1991).

Mature trees of the genus Terminalia generally possess extensive flat top with a wide horizontal canopy and foliage that are evenly distributed and arising from the apex of the straight stem (Dupuy and Mille, 1993). These characteristics, and the relatively fast growth, that make T. Ivorensis Chev., T. mantaly H. Perrier and T. superba Engler $\&$ Diels popular timber species. Other species, such as T. sericea Burch. ex DC. and T. prunioides Laws. are common as small shrubs to bushy trees that may be single or multi-stemmed with a girth of up to $1.5 \mathrm{~m}$ (Coates-Palgrave, 1977).

The bark of Terminalia trees is smooth and light grey to dark brown when young and on branchlets. The inner bark and contact zone with the cambium is frequently yellow. In mature trees, the bark surface cracks and flakes off in long thin strips or small patches, often becoming blackish and developing deep longitudinal fissures as the trees grow (Keay, 1989; Lemmens et al., 1995).

The leaves are frequently simple and obovate, clustered spirally at the ends of the dwarfed lateral branchlets, or crowded near the ends of the branches. Some species, like T. brassii Exell., have prominent glands at the leaf bases (Lamb and Ntima, 1971). In mature trees the crown is usually flat or very slightly domed; giving Terminalia trees a distinctive shape. Some species, such as T. ivorensis, T. superba and T. mantaly, develop as elements of the canopy or sub-canopy layer in evergreen, semi- deciduous to deciduous, primary and secondary forests, whereas species such as $T$. sericea, thrive well in open woodlands and mixed deciduous forests.

Terminalia spp. provides economical, medicinal, spiritual and social benefits. The wood of Terminalia spp. is highly appreciated as constructional timber. It is currently used for light construction, door and window frames, coffin boards, mouldings, beams, rafters, flooring, furniture, carts, tool handles, spindles, shuttles, picker sticks, walking sticks, boat building, foundation piles and plywood (Irvine 1961; Lemmens et al., 1995; Schmidt et al., 2002; Smith et al., 2004). The fruits and barks of T. sericea and T. catappa L. are important sources of tannin, as well as gum and resins for glazing pottery (Irvine 1961; Lemmens and Wulijarni-Soetjipto 1991; Ellery and Ellery 1997). Dyes of various colours (black, red, orange, yellow, brown) are extracted from the leaves, fruits, bark and roots of species such as $T$. mollis Lawson, T. ivorensis, T. laxiflora Engl. \& Diels., T. catappa and T. superba, and are used for clothes dyeing, mattings, spoons and walking sticks (Dalziel 1937; Errington and Chisumpa 1987). The seed of some species such as T. catappa are edible and considered one of the best flavoured tropical nuts. Furthermore, consumable oil can be extracted from the seed of T. catappa and used as a substitute for groundnut (Arachis hypogea L.), cotton seed (Gossypium spp.) and silk cotton seed (Ceiba spp.) oils (Irvine, 1961).

In view of the complex taxonomic status in the genus and the difficulty in identifying members of the genus morphologically, this study therefore set out to describe the leaf and petiole anatomy of five species of the genus Terminalia with a view to providing useful additional information for the delimitation, subsequent identification and the taxonomy of the genus with respect to the characters viz, nature of epidermis, thickness of upper and lower 
cuticle, number of layers of palisade mesophyll cells and length, number of layers of parenchymatous cells in pith, type of vascular bundles, occurrence of cortical and pericyclic fibre, etc. The representative species of the genus include T. catappa L., T. superba Engl. \& Diels., T. ivorensis A. Chev., T. mantaly H. Perr. and T. avicennioides Guill. \& Perr.

\section{Materials and methods}

\section{Study area and target species}

The present study was undertaken in South-Western Nigeria (Figure 1). The area, according to
Agboola (1979), lies between Longitude $2^{\circ} 31^{\prime} \mathrm{E}$ and $6^{\circ} 00^{\prime} \mathrm{E}$ and Latitude $6^{\circ} 21^{\prime} \mathrm{N}$ and $8^{\circ} 37^{\prime} \mathrm{N}$. The climate of Southwestern Nigeria is tropical in nature, characterised by wet and dry seasons with temperature ranging between $21{ }^{\circ} \mathrm{C}$ and $34{ }^{\circ} \mathrm{C}$ and annual rainfall of about $150 \mathrm{~mm}$ to $3,000 \mathrm{~mm}$ (Faleyimu et al., 2013). Collection of plants were made from different locations and the site of collection georeferenced with a GPS device (Table 1). Two to five accessions were considered for each species and five to ten matured leaves examined from different parts of the plants in each of the accessions.

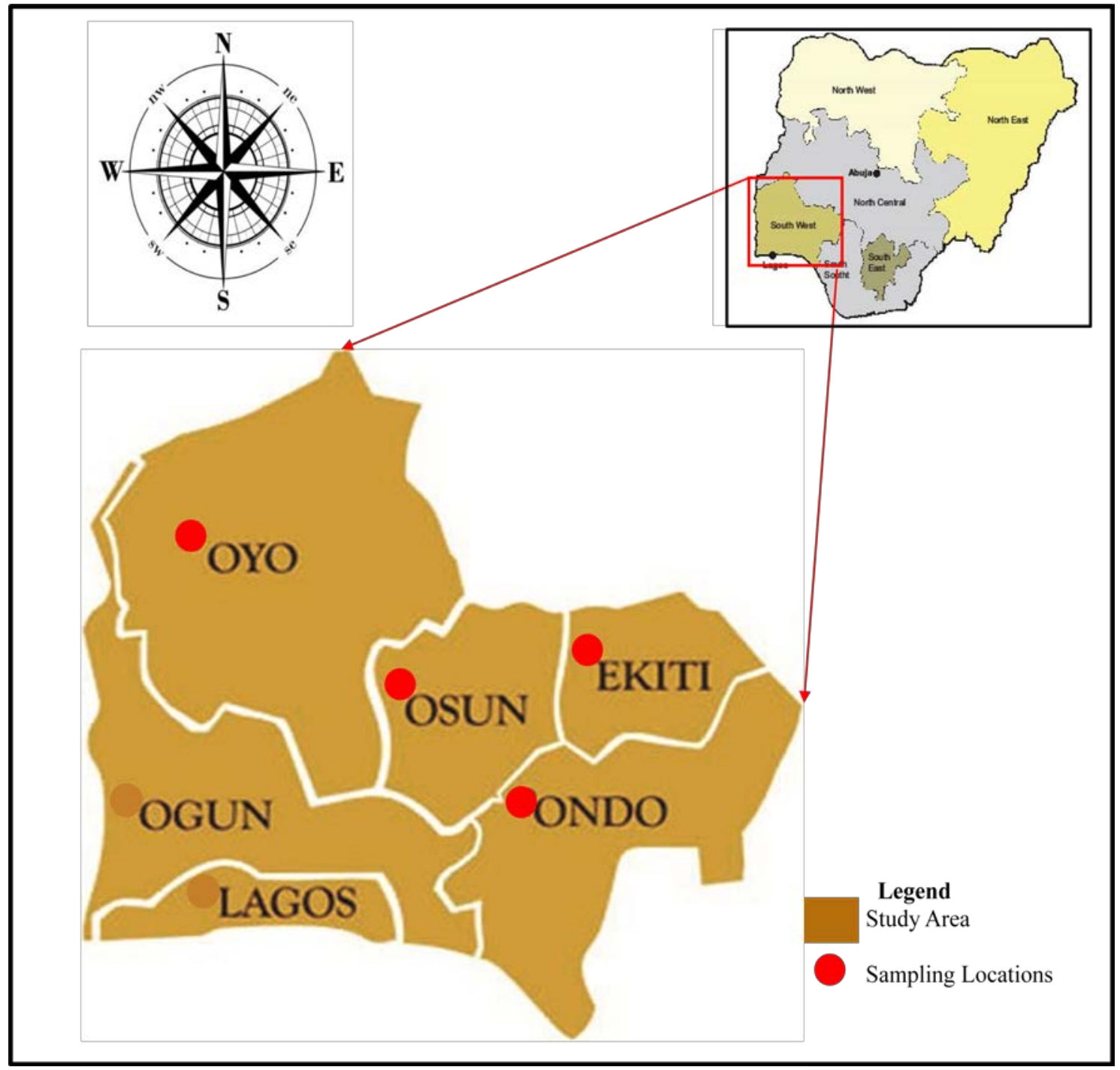

Figure1. Map of Nigeria showing the sampling locations in south-west. 
Table 1. Site of Collection and Geographic Location of species of Terminalia.

\begin{tabular}{|c|c|c|}
\hline Species & Location/Site of Collection & Geographic Location \\
\hline T. catapa & $\begin{array}{l}\text { Murtala Mohammed PG Hall, OAU, Ile-Ife, Osun } \\
\text { State }\end{array}$ & $\begin{array}{l}07^{\circ} 31.341^{\prime} \mathrm{N} \\
04^{\circ} 30.986^{\prime} \mathrm{E}\end{array}$ \\
\hline T. catapa & Department of Botany, OAU, Ile-Ife, Osun State & $\begin{array}{l}07^{\circ} 31.174^{\prime} \mathrm{N} \\
04^{\circ} 31.551^{\prime} \mathrm{E}\end{array}$ \\
\hline T. catapa & Oke-Offa Street, Igbindo Town, Ondo State & $\begin{array}{l}06^{\circ} 57.2617^{\prime} \mathrm{N} \\
04^{\circ} 42.4307^{\prime} \mathrm{E}\end{array}$ \\
\hline T. catapa & University of Ibadan, Ibadan, Oyo State & $\begin{array}{l}07^{\circ} 23.62^{\prime} \mathrm{N} \\
03^{\circ} 39.18^{\prime} \mathrm{E}\end{array}$ \\
\hline T. superba & Igbindo Town, OWLG, Ondo, Ondo State & $\begin{array}{l}06^{\circ} 57.2727^{\prime} \mathrm{N} \\
04^{\circ} 42.9308^{\prime} \mathrm{E}\end{array}$ \\
\hline T. superba & Gbonagwa Village, via Ondo, Ondo State & $\begin{array}{l}07^{\circ} 36.02^{\prime} \mathrm{N} \\
04^{\circ} 45.8986^{\prime} \mathrm{E}^{\prime}\end{array}$ \\
\hline T. ivorensis & Chemical Engn. Dept., OAU, Ile-Ife, Osun State & $\begin{array}{l}07^{\circ} 31.185^{\prime} \\
04^{\circ} 31.599^{\prime} \mathrm{E}\end{array}$ \\
\hline T. ivorensis & C.A.C Grammar School, Oka-Ondo, Ondo State & $\begin{array}{l}07^{\circ} 04.3820^{\prime} \mathrm{N} \\
04^{\circ} 49.8029^{\prime} \mathrm{E}\end{array}$ \\
\hline T. ivorensis & Off Ikere-Ekiti Road, Ado-Ekiti, Ekiti State & $\begin{array}{l}07^{\circ} 376.994^{\prime} \mathrm{N} \\
05^{\circ} 132.0216^{\prime} \mathrm{E}\end{array}$ \\
\hline T. ivorensis & Igbindo Town, OWLG, Ondo, Ondo State & $\begin{array}{l}06^{\circ} 42.4132^{\prime} \mathrm{N} \\
04^{\circ} 48.9639^{\prime} \mathrm{E}\end{array}$ \\
\hline T. mantaly & Social Sciences Block, OAU, Ile-Ife, Osun State & $\begin{array}{l}07^{\circ} 31.286 \mathrm{~N} \\
04^{\circ} 31.383 \mathrm{E}\end{array}$ \\
\hline T. mantaly & Oloruntele Village, Ile-Ife Road, Ondo State & $\begin{array}{l}07^{\circ} 08.9148^{\prime} \mathrm{N} \\
04^{\circ} 45.1463^{\prime} \mathrm{E}\end{array}$ \\
\hline T. mantaly & Valentino Street, Ile-Ife Road, Ondo, Ondo State & $\begin{array}{l}07^{\circ} 04.3932^{\prime} \mathrm{N} \\
04^{\circ} 49.7466^{\prime} \mathrm{E}\end{array}$ \\
\hline T. mantaly & $\begin{array}{l}\text { Nigeria Immigration Office Road, Ado-Ekiti, Ekiti } \\
\text { State }\end{array}$ & $\begin{array}{l}07^{\circ} 380.822 \mathrm{~N} \\
05^{\circ} 130.09615^{\prime} \mathrm{E}\end{array}$ \\
\hline T. mantaly & University of Ibadan, Ibadan, Oyo State & $\begin{array}{l}07^{\circ} 23.37^{\prime} \mathrm{N} \\
03^{\circ} 36.20^{\prime} \mathrm{E}\end{array}$ \\
\hline T. avicennioides & Awo Community, Ejigbo Road, Ede, Osun State & $\begin{array}{l}07^{\circ} 46.270^{\prime} \mathrm{N} \\
04^{\circ} 24.365^{\prime} \mathrm{E}\end{array}$ \\
\hline T. avicennioides & Awo Community, Ejigbo Road, Ede, Osun State & $\begin{array}{l}07^{\circ} 46.270^{\prime} \mathrm{N} \\
04^{\circ} 24.322^{\prime} \mathrm{E}\end{array}$ \\
\hline T. avicennioides & Awo Community, Ejigbo Road, Ede, Osun State & $\begin{array}{l}07^{\circ} 46.290^{\prime} \mathrm{N} \\
04^{\circ} 24.422 \mathrm{E}\end{array}$ \\
\hline T. avicennioides & Awo Community, Ejigbo Road, Ede, Osun State & $\begin{array}{l}07^{\circ} 46.138 \mathrm{~N} \\
04^{\circ} 24.312 \mathrm{E}\end{array}$ \\
\hline
\end{tabular}

\section{Methodology}

The transverse sections of leaves and petioles of all the species were cut using Reichert Sliding Microtome at a thickness of 8-10 microns. The sections were stained in Safranin 0 for 3-5 min, rinsed thoroughly in water to remove excess stain and counterstained in Alcian Blue solution for 3-5 min. The sections were again washed with water and treated in series of ethanol dilution-50\%, $70 \%, 80 \%, 90 \%$ and $100 \%$ to enhance dehydration process. The dehydrated sections were transferred into absolute xylene to remove any remaining trace of water and ethanol. These made sections clearer and prevented cloudiness of the slide. Sections were therefore mounted in $25 \%$ glycerol containing thymol crystals to prevent fungal attack, on a clean glass slide for light microscopy. 


\section{Data analysis}

Data generated from the documentation were subjected to Analysis of Variance and Multivariate Statistical Analysis. Principal Components Analysis and Cluster Analysis was carried out on the quantitative data using PAlaentological STatistics (PAST). Photomicrographs of all anatomical features were made with the aid of Accu-sccope Trinocular Microscope (Accu-scope 33001 LED Trinocular Microscope with 3.2 MP CMOS Digital Camera). All quantitative parameters were taken with the aid of ocular micrometer and final figures derived with ocular constant.

\section{Results}

\section{Terminalia catapa}

Leaf and petiole anatomy. Leaf is dorsiventral/bifacial, epidermis is uniseriate with mostly rectangular cells with thick cuticle, mean thickness of upper cuticle is $23.00 \pm 0.56 \mu \mathrm{m}$. Palisade mesophyll consist of one layer of cells, occurring on the adaxial surface and composed of compactly arranged cylindrical cells (Plate 1A), mean length of palisade mesophyll cell is $66.88 \pm 0.64$ $\mu \mathrm{m}$. Spongy mesophyll cells are largely irregular in shape, irregularly arranged with large intercellular air spaces, mean thickness of lower cuticle is $18.50 \pm 0.53$ $\mu \mathrm{m}$. Vascular bundle is collateral, C-shaped and continuous. Pith comprises of parenchymatous cells and large airspaces (Plate 1B). In Transverse section, petiole outline is generally triangular. The epidermis is uniseriate and comprises of small sized, oval to barrel- shaped cells with thick outer walls (Plate 2A). The cortex is 2-4 layered of angular collenchyma; followed by mass of thin-walled parenchyma of oval to polygonal cells. The vascular bundle is collateral, pericyclic fibre attached to the phloem in the vasculature. Pith comprises of oval to polygonal parenchyma cells. The vascular ring is continuous, forming an inverted V-shape abaxially but arched adaxially (Plate 1A). Simple unicellular, trichome is present (Plate 1B).

\section{Terminalia superba}

Leaf and petiole anatomy. Leaf is dorsiventral/bifacial, epidermis uniseriate with mostly rectangular cells, cuticle present and thin, mean thickness of upper cuticle is $13.00 \pm 0.56 \mu \mathrm{m}$, palisade mesophyll cells one layer thick, occurring on the adaxial surface and composed of closely packed cylindrical cells (Plate 1C), mean length of palisade mesophyll cell is $46.88 \pm 0.68 \mu \mathrm{m}$. Spongy mesophyll cells are largely irregular in shape, irregularly arranged with intercellular air spaces (Plate 1C), mean thickness of lower cuticle is $12.25 \pm 0.57$ $\mu \mathrm{m}$. Vascular bundles type is collateral, dissected with three strands, arched or deeply crescentiform, Simple, unicellular trichome is observed, trichomes are short and occur only on the midrib region, midrib deeply grooved (Plate 1D). In transverse section, the petiole outline is generally oval or slightly triangular with slight grooves of depression. The epidermis is uniseriate and comprises of small sized, oval or barrel- shaped cells, cortex is made of 4-5 layers of angular collenchyma, followed by thin-walled parenchyma of oval to polygonal cells (Plate 2C). The vascular bundle is collateral, consisting of xylem and phloem lying on the same radius, phloem to the outside of the xylem (Plate 2D). Pith comprises of oval to polygonal parenchyma cells. The vascular ring is single continuous but partially opens inwardly (invaginated) adaxially (Plate 2C and 2D). Simple unicellular trichome present, sparsely distributed (Plate 2D). 

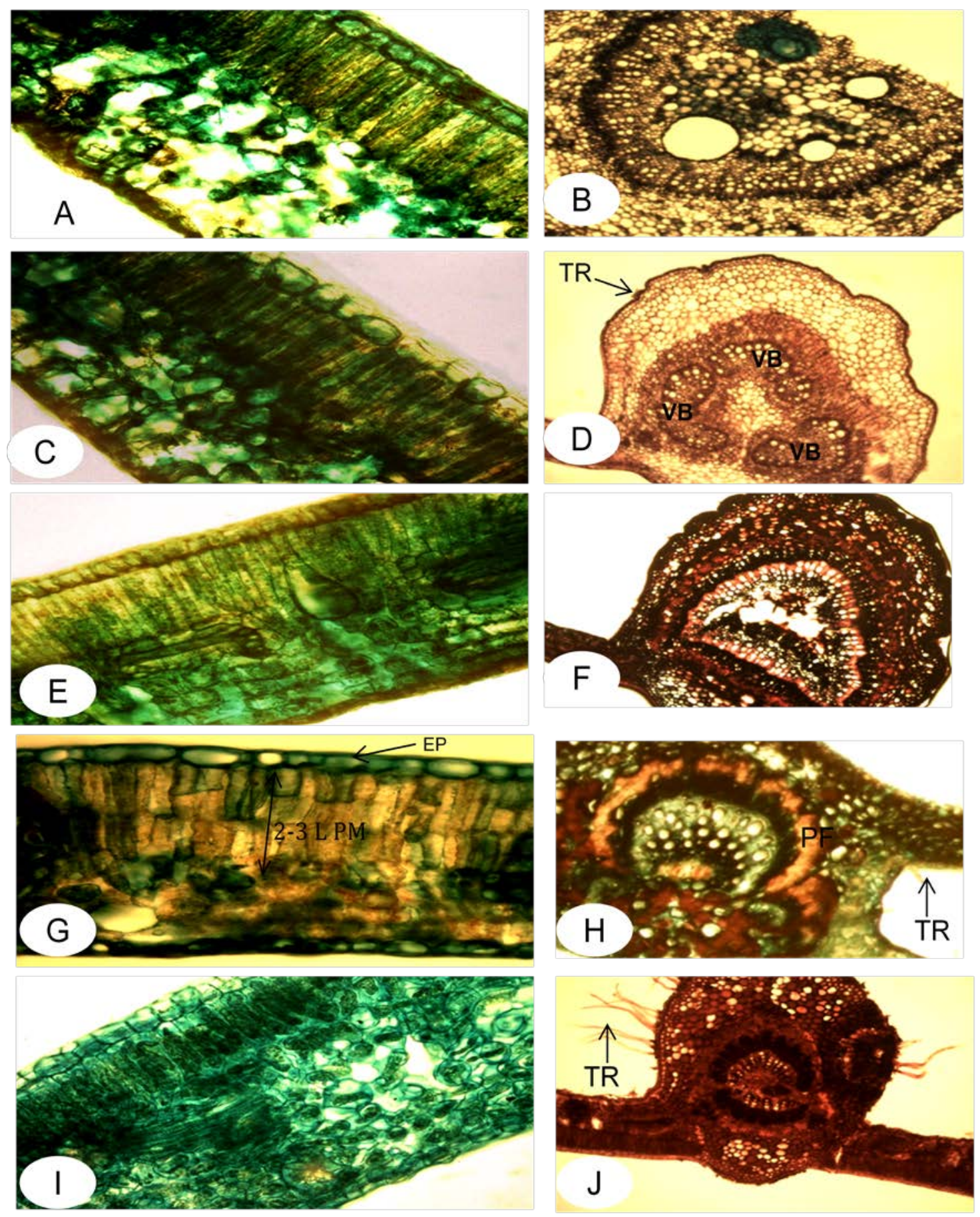

$52.1 \mu \mathrm{m}$

Plate 1. Photomicrographs of Transverse Section of Lamina of five species of Terminalia. (A) Transverse Section of Leaf (Lamina), and (B) midrib of T. catapa; (C) Transverse Section of Leaf (lamina), and (D) midrib of T. superb; (E) Transverse Section of Leaf (Lamina), and (F) midrib of $T$. Ivorensis; (G) Transverse Section of Leaf (Lamina) and (H) midrib of T. Mantaly; (I) Transverse Section of Leaf (Lamina) and (J) midrib of T. Avicennioides. $\mathrm{TR}=$ Trichome, $\mathrm{EP}=$ Epidermis, LPM $=$ Layers of Palisade Mesophyll, V.B. $=$ Vascular Bundle, $\mathrm{PF}=$ Pericyclic Fibre. $T \mathrm{~m}=$ T. mantaly, $\mathrm{Tc}=T$. catapa, $\mathrm{Ti}=T$. ivorensis, $\mathrm{Ta}=T$. avicennioides, $\mathrm{Ts}=T$. superba . 

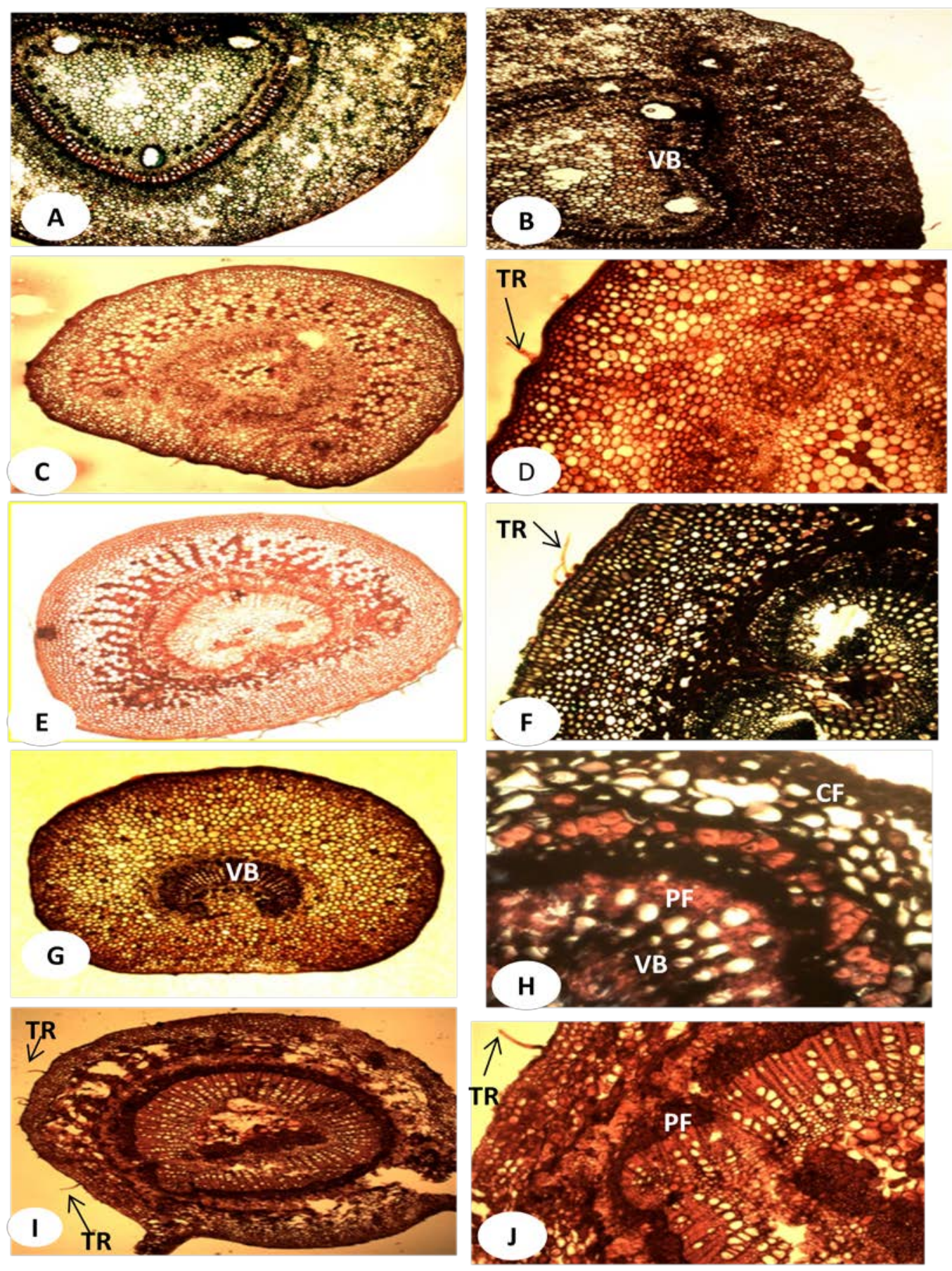

$47.1 \mu \mathrm{m}$

Plate 2. Photomicrographs of Transverse Section of Petiole of five species of Terminalia. A and B: Transverse Section of petiole of T. Catapa. (C and D): Transverse Section of petiole of $T$. Superb. (E and F): Transverse Section of petiole of T. Ivorensis. (G and H): Transverse Section of petiole of T. Mantaly. (I and J): Transverse Section of petiole of T. Avicennioides. TR=Trichome, V.B=Vascular Bundle, $\mathrm{PF}=$ Pericyclic Fibre, $\mathrm{CT}=$ Cortical Fibre. 


\section{Terminalia ivorensis}

Leaf and petiole anatomy. Leaf is dorsiventral/bifacial, epidermis is uniseriate with more or less rectangular cells, cuticle present and thin, mean thickness of upper cuticle is $12.00 \pm 0.56$ $\mu \mathrm{m}$, palisade mesophyll cells one layer thick, occurring on the adaxial surface and composed of compactly arranged cylindrical cells, mean length is $56.88 \pm$ $0.90 \mu \mathrm{m}$. Spongy mesophyll cells largely irregular in shape, irregularly arranged with fairly large intercellular air spaces (Plate 1E), mean thickness of lower cuticle is $11.75 \pm 0.55 \mu \mathrm{m}$, Vascular bundles collateral, continuous and triangular, pericyclic fibre present (Plate $1 \mathrm{~F})$, simple, unicellular trichome present and occur on the midrib region (Plate $1 \mathrm{~F})$, midrib deeply grooved. In transverse section, petiole outline is slightly oval to slightly triangular. The epidermis is uniseriate and comprises of small sized, rounded to barrel- shaped epidermal cells with thick outer walls (Plate 2E). The cortex is a 4-6 layered angular collenchymas; followed by a mass of thin-walled parenchyma of oval to polygonal cells. The vascular bundle is collateral (Plate 2E and F); pith comprises of oval to polygonal parenchyma cells. The vascular ring is continuous and invaginated, capped from outside by 1-2 layered pericyclic fibre (Plate 2F). Simple unicellular trichomes present (Plate $2 \mathrm{~F}$ ).

\section{Terminalia mantaly}

Leaf and petiole anatomy. Leaf dorsiventral/bifacial, epidermis uniseriate with rectangular cells and thick cuticle, mean thickness of upper cuticle is $27.00 \pm 0.56 \mu \mathrm{m}$, palisade mesophyll cells are closely packed cylindrical cells, occasionally irregular (Plate 1G), mostly two layers thick, occasionally three layered, occurring on the adaxial surface, mean length is $106.38 \pm 0.98 \mu \mathrm{m}$. Spongy mesophyll cells largely irregular in shape with intercellular air spaces (Plate 1G), mean thickness of lower cuticle is $25.25 \pm 0.25$ $\mu \mathrm{m}$, Vascular bundles collateral, deeply crescentiform or lunar-shaped, pericyclic fibres present (Plate 1H). Simple, unicellular trichome present and occur only on the midrib region (Plate $1 G$ ). In transverse section, petiole outline is broadly oval; epidermis is uniseriate, consisting of small to medium sized barrel shaped or polygonal cells with outer thick walls (Plate 2G). Cortex is 2-4 layered outer collenchyma, and inner parenchyma of 2-5 layers. Collenchyma mainly angular with oval to polygonal cells, and 2-4 layered (Plate 2G). Vascular bundle is collateral (Plate 2G and $\mathrm{H}$ ), pith comprises of rounded to polygonal parenchyma cells. The vascular ring is continuous and invaginated, cortical and pericyclic fibres present (Plate $2 \mathrm{H}$ ).

\section{Terminalia avicennioides}

Leaf and petiole anatomy. Leaf dorsiventral/bifacial, epidermis uniseriate with rectangular or polygonal cells, cuticle present and thick, mean thickness of upper cuticle is $21.00 \pm 0.46$ $\mu \mathrm{m}$, palisade mesophyll cells one layer thick, occurring on the adaxial surface and composed of closely packed more or less cylindrical cells (Plate 1I), mean length is $99.00 \pm 2.35 \mu \mathrm{m}$. Spongy mesophyll cells oval, sometimes polygonal and irregularly packed with intercellular air spaces (Plate 1I), mean thickness of lower cuticle is $21.00 \pm 0.46$ $\mu \mathrm{m}$. Vascular bundles collateral (Plate 1J), arched or crescentiform. Numerous Simple unicellular trichomes were present, mainly attached to the epidermis of the midrib; rarely on lamina. In transverse section, petiole outline it is generally circular to oval (Plate 2I). The epidermis is uniseriate and comprises of small sized, rounded to barrel- shaped cells with thick outer walls (Plate 2J). Cortex consists of 4-5 layers of angular collenchyma, followed by thin-walled parenchyma of oval to polygonal cells, cortical and pericyclic fibre present (Plate 2J). The vascular bundle is collateral; pith comprises of 
oval to polygonal parenchyma cells. The vascular ring is continuous, simple unicellular trichomes present (Plate 2J)

\section{Discussion}

Leaf lamina anatomy. Leaf anatomy provides a variety of features that could be used for taxonomic purposes (Carlquist, 1961). Some researchers have utilized leaf anatomy for taxonomic consideration in different species of plants (Illo, 1995) on the genus Celosia, Adedeji (2004) on Emilia, Adedeji and Illoh (2004) on the genus Hibiscus, Okeke et al. (2015) on the genus Stachyterpheta, Rodriguez et al. (2016) on species of a Tamaulipan Thorn Scrub Forest, e.t.c.) The five species of Terminalia studied show some variations in their leaf anatomy. Characters such as shape and length of palisade mesophyll cells, thickness of upper and lower cuticle, types and shapes of vascular bundles, presence/absence of pericyclic fibres, presence/absence of trichome and abundance are important in establishing relationship among members of this genus. Thin cuticle classifies T. superba and $T$. ivorensis while $T$. catapa, $T$. mantaly and T. avicennioides are grouped on the basis of thick upper and lower cuticle (Table 2). The shape of vascular ring is also a good tool to delimit the taxa studied. It ranges from triangular (as in T. ivorensis) through ' $\mathrm{C}$ ' or lunar-shaped (as in T. catapa and T. mantaly) to slightly or deeply crescentiform (as in $T$. superba and T. avicennioides); while the presence of vascular bundles with dissected three strands in the midrib region is diagnostic for $T$. superba (Plate $1 \mathrm{D}$, Table 2). In this study, T. mantaly is clearly delineated from its close relatives by the possession of 2-3 layers of palisade mesophyll cells (Plate 1G, Table $2)$. Thus, the 2-3 layered palisade mesophyll cells is diagnostic for the species. However, this parameter was also utilized by Ayensu (1974) in separating members of the genus Vellozia. Simple unicellular trichome classifies $T$. superba, T. ivorensis, $T$. mantaly and T. avicennioides. Whereas, lacking in T. catapa, hence diagnostic for the species (Plate $1 \mathrm{~B}$ and Table 2). Dorsiventral leaf, uniseriate epidermis and collateral vascular bundle were all found to be generic. Pericyclic fibre in the midrib region of the leaf is classificatory for $T$. ivorensis and $T$. mantaly. The dendogram of the species (Figure 2) revealed that $T$. ivorensis and $T$. avicennioides are with the highest level of similarity as T. superba also shares some closeness to them. The closeness observed in T. mantaly and T. catapa may have originated from the slight closeness in their leaf anatomy and common ancestry. The PCA scattered diagram (Figure 3) revealed the similarities in the genus, The closeness observed between T. ivorensis and T.superba as well as T. avicennioides and T. mantaly is evident in their quantitative leaf anatomical character (Table 2), hence their sectional classification. The PCA factor loadings (Table 5) revealed that the taxa could be separated by the anatomical attributes stated and since they had high factor loadings, the characters are important in delimiting members of the genus Terminalia studied, and are the characters responsible for the variation observed. 
Table 2. Summary of qualitative and quantitative leaf anatomical characters of five species of Terminalia.

\begin{tabular}{|c|c|c|c|c|c|c|}
\hline $\begin{array}{c}\text { Characters } \\
\text { Species }\end{array}$ & Leaf & Epidermis & Cuticle & MTUC $(\mu \mathrm{m})$ & MTLC $(\mu \mathrm{m})$ & LPMC \\
\hline T. catapa & Dorsiventral & Uniseriate & Thick & $23.00 \pm 0.56$ & $18.50 \pm 0.53$ & 1 \\
\hline T. superba & Dorsiventral & Uniseriate & Thin & $13.00 \pm 0.56$ & $12.25 \pm 0.57$ & 1 \\
\hline T. ivorensis & Dorsiventral & Uniseriate & Thin & $12.00 \pm 0.56$ & $11.75 \pm 0.55$ & 1 \\
\hline T. mantaly & Dorsiventral & Uniseriate & Thick & $27.00 \pm 0.56$ & $25.25 \pm 0.25$ & $2-3$ \\
\hline T. avicennioides & Dorsiventral & Uniseriate & Thick & $21.00 \pm 0.46$ & $21.00 \pm 0.46$ & 1 \\
\hline $\begin{array}{c}\text { Characters } \\
\text { Species }\end{array}$ & $\begin{array}{c}\text { MLPMC } \\
(\mu \mathrm{m})\end{array}$ & $\begin{array}{c}\text { Type of } \\
\text { vascular } \\
\text { bundle }\end{array}$ & $\begin{array}{c}\text { Shape of } \\
\text { vascular ring }\end{array}$ & $\mathbf{T}$ & TP & PF \\
\hline T. catapa & $66.88 \pm 0.64$ & Collateral & C-shaped & - & - & - \\
\hline T. superba & $46.88 \pm 0.68$ & Collateral & $\begin{array}{c}\text { Dissected/ } \\
\text { crescentiform }\end{array}$ & + & SUT & - \\
\hline T. ivorensis & $56.88 \pm 0.68$ & Collateral & Triangular & + & SUT & + \\
\hline T. mantaly & $106.36 \pm 0.98$ & Collateral & Lunar-shaped & + & SUT & + \\
\hline T. avicennioides & $99.00 \pm 2.35$ & Collateral & $\begin{array}{c}\text { Crescentiform/ } \\
\text { arched }\end{array}$ & + & SUT & - \\
\hline
\end{tabular}

MTUC = Mean thickness of upper cuticle; MTLC = Mean thickness of lower cuticle; LPMC = Layer of palisade mesophyll cells; MLPMC = Mean length of palisade mesophyll cells; T = Trichome; TP $=$ Trichome Type. + : Present, - : Absent, SUT: Simple Unicellular Trichome.

Petiole anatomy. Data obtained from anatomy can be amply used for taxonomic and phylogenetic purposes (Illoh 1998). The data recorded in this study are sufficient for the taxa to be distinguished from one another taxonomically as all the species showed marked variations for all petiole anatomical characters considered. In this genus, uniseriate epidermis, angular collenchyma, oval to polygonal parenchyma was all found to be generic (Plate 2A-J and Table 3). Triangular petiole outline delimits T. catapa as others ranges from oval to circular (Table 3). Cortical fibre in the cortical regions of the petiole groups T. catapa, $T$. mantaly and $T$, avicennioides (Table 3 ) just as the presence of fibre in the pericyclic region is classificatory for $\mathrm{T}$. ivorensis, T. mantaly and T. avicennioides. However, among all the species, Terminalia mantaly was observed to be the only taxon lacking trichome. The type, number and shape of vascular bundles were adopted in separating members of the genus Terminalia studied. Variations of taxonomic significance occur in the vascular anatomy of the petioles, though collateral vascular bundles appear to be a generic character. The shapes and arrangement of the vascular bundles are important in classifying the five taxa though few characters are diagnostic. Single, inverted 'V - shaped' and adaxially arched vascular bundle is peculiar only to T. catapa; Single, continuous and invaginated strand is common to $T$. superba, T. ivorensis and T. mantaly. The presence of two ribs as well as single and continuous vascular strand is a spot character for T. avicennioides. The type, number and shape of vascular bundles as was adopted in this study was used by Ayensu (1968) in separating three genera-Croomia, Stemona and Stychoneuron in the family Stemonaceae. The presence of pericyclic and cortical fibre groups $T$. mantaly and $T$. avicennioides, and so classificatory for the two species. It is therefore recommended that evidences from the petiole anatomy as recorded in this study are important in the generic delimitation of members of the genus Terminalia investigated. 
Table 3. Summary of qualitative and quantitative petiole anatomical characters.

\begin{tabular}{|l|c|c|c|c|}
\hline $\begin{array}{l}\text { Characters } \\
\text { species }\end{array}$ & Petiole outline & $\begin{array}{c}\text { Type of } \\
\text { Epidermis }\end{array}$ & $\begin{array}{c}\text { No. of cell layer } \\
\text { in the Cortex }\end{array}$ & Cortical Fibre \\
\hline T. catapa & Triangular & Uniseriate & $2-4$ & + \\
\hline T. superba & Oval & Uniseriate & $4-5$ & - \\
\hline T. ivorensis & Oval/triangular & Uniseriate & $4-6$ & + \\
\hline T. mantaly & Oval & Uniseriate & $2-5$ & + \\
\hline T. avicennioides & Circular/oval & Uniseriate & 3 & Trichome type \\
\hline $\begin{array}{l}\text { Characters } \\
\text { species }\end{array}$ & Pericyclic Fibre & Vasculature & Trichome & SUT \\
\hline T. catapa & - & Continuous & + & SUT \\
\hline T. superba & - & Single continuous & + & SUT \\
\hline T. ivorensis & + & $\begin{array}{c}\text { Continuous/ } \\
\text { invaginated }\end{array}$ & + & - \\
\hline T. mantaly & + & Continuous $/$ & + & SUT \\
\hline T. avicennioides & + & Continuous & + & + \\
\hline
\end{tabular}

+ : Present, - : Absent, SUT: Simple Unicellular Trichome.

Table 4. Leaf anatomical characters of five species of terminalia with duncan multiple mean separation.

\begin{tabular}{|l|c|c|c|}
\hline Characters species & LPL & TUC & TLC \\
\hline T. catappa & $66.88 \pm 0.64^{\mathbf{c}}$ & $23.00 \pm 0.56^{\mathbf{c}}$ & $18.50 \pm 0.53^{\mathbf{b}}$ \\
\hline T. superba & $46.88 \pm 0.68^{\mathrm{a}}$ & $13.00 \pm 0.56^{\mathrm{a}}$ & $12.25 \pm 0.57^{\mathrm{a}}$ \\
\hline T. ivorensis & $56.88 \pm 0.68^{\mathbf{b}}$ & $12.00 \pm 0.56^{\mathrm{a}}$ & $11.75 \pm 0.55^{\mathbf{a}}$ \\
\hline T. mantaly & $106.36 \pm 0.98^{\mathrm{e}}$ & $27.00 \pm 0.56^{\mathbf{d}}$ & $25.25 \pm 0.25^{\mathbf{d}}$ \\
\hline T. avicennioides & $99.00 \pm 2.35^{\mathrm{d}}$ & $21.00 \pm 0.46^{\mathbf{b}}$ & $21.00 \pm 0.46^{\mathbf{c}}$ \\
\hline
\end{tabular}

*Means with the same alphabet along the same column are not significantly different. LPL $=$ Length of Palisade Layer, TUC $=$ Thickness of Upper Cuticle, TLC $=$ Thickness of Lower Cuticl.

Table 5. PCA Factor loadings for important quantitative leaf and petiole anatomical characters of five species of Terminalia.

\begin{tabular}{|c|c|c|c|}
\hline Characters & PCA1 & PCA2 & PCA3 \\
\hline $\begin{array}{c}\text { Length of Palisade } \\
\text { Mesophyll Cells }\end{array}$ & 0.9386 & - & - \\
\hline $\begin{array}{c}\text { Thickness of } \\
\text { Upper Cuticle }\end{array}$ & 0.9630 & - & - \\
\hline $\begin{array}{c}\text { Thickness of } \\
\text { Lower Cuticle }\end{array}$ & 0.9908 & - & - \\
\hline
\end{tabular}




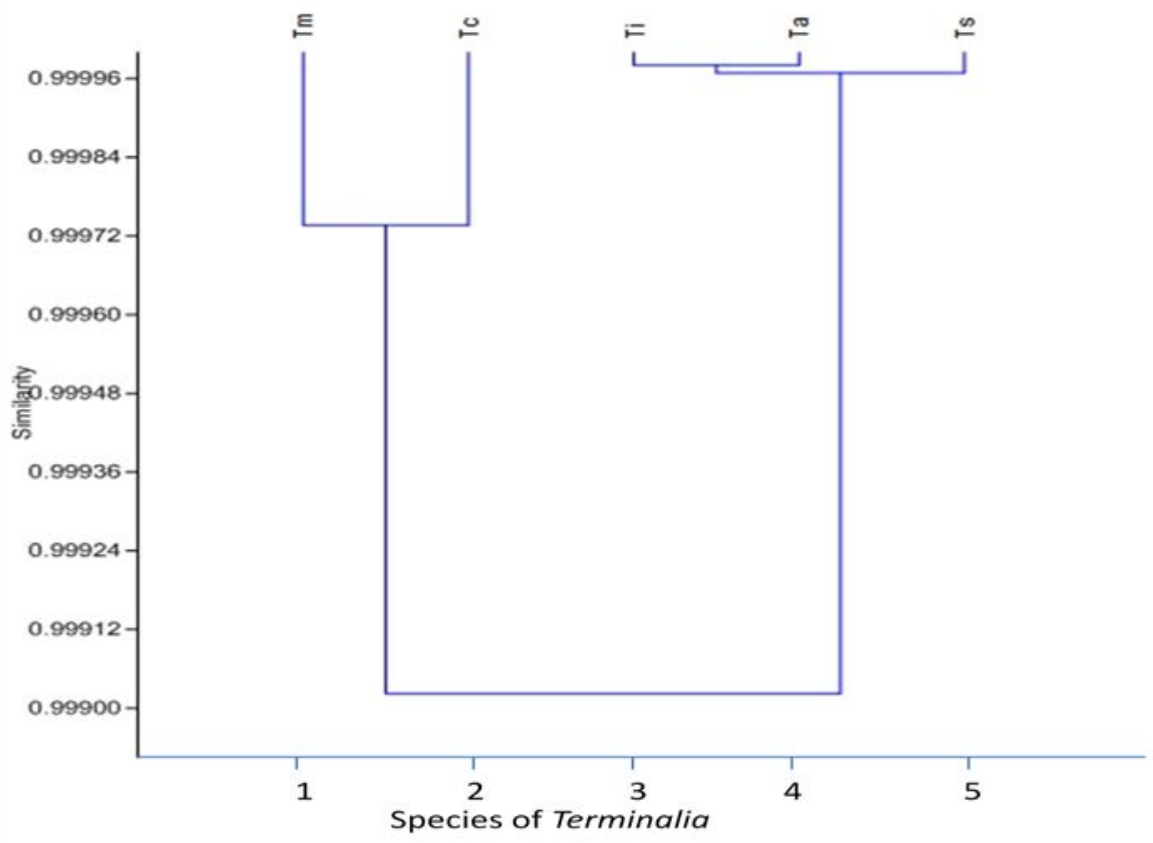

Figure 2. Dendogram of Terminalia species based on quantitative leaf anatomical character. $\mathrm{Tm}=T$. mantaly, $\mathrm{Tc}=T$. catapa, $\mathrm{Ti}=T$. ivorensis, $\mathrm{Ta}=T$. avicennioides, $\mathrm{Ts}=T$. superba .

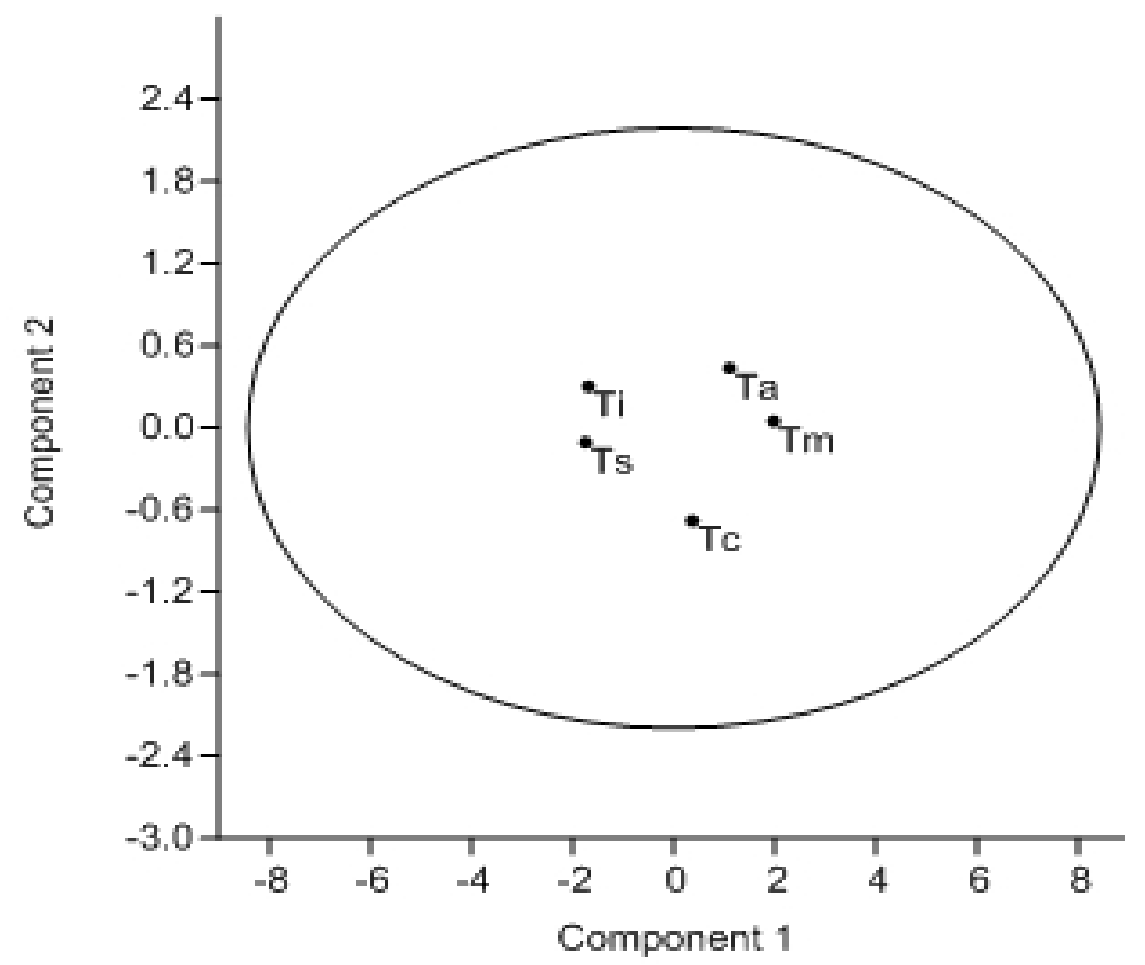

Figure 3. PCA scattered diagram of five species of terminalia based on quantitaive leaf anatomical characters. 


\section{Acknowledgement}

We acknowledge the contribution of the former curator of IFE Herbarium, $\mathrm{Mr}$ Ibhanesebhor, as well as $\mathrm{Mr}$ Omomoh Berrnard of the Department of Forestry and Wood Technology, Federal University of Technology, Akure. We also appreciate the effort of Mr Adelalu Kole and Mr Omole Abiodun of the Histology Laboratory, Department of Botany, Obafemi Awolowo University, Ile-Ife, for providing technical supports involving anatomy.

\section{Conflict of interest}

The authors have declared that there is no conflict of interest.

\section{References}

Adedeji, O. A. Leaf epidermal studies of the species of Emilia Cass. (Senecioneae, Asteraceae) in Nigeria, Botanical Lithuanica, v. 10, no. 2, p. 121-133, 2004.

Adedeji, O. A.; Illoh, H. C. Comparative foliar anatomy of the genus Hibiscus Linn. in Nigeria. New Botanist, v. 31, p. 147-180, 2004.

Agboola, S. A. An Agricultural Atlas of Nigeria. Nigeria: Oxford University Press, 1979.

Ayensu, E. S. Comparative vegetative anatomy of the Stemonaceae (Roxburghiaceae). Bot. Gaz., v. 129, p. 160165, 1968.

Carlquist, S. Comparative plant anatomy. New York: Holt, Rinehart and Winston, 1961.

Coates Palgrave, K. Trees of Southern Africa. 1. ed. Cape Town: Struik, 1977.

Dalziel, J. M. Useful plants of West Tropical Africa. London: Crown Agents, 1937.

Dupuy, B.; Mille, G. Timber plantations in the humid tropics of Africa. FAO Forestry Paper. Rome: FAO, 1993. (No. 98).

Ellery, K.; Ellery, W. Plants of the Okavango Delta: A field guide. Durban: Tsaro Publisher, 1997.

Errington, L.; Chisumpa, S. M. Natural Dyes of Zambia. Ndola: Mission Press, 1987.
Faleyimu, 0. I.; Agbeja, B. 0.; Akinyemi, 0. State of forest regeneration in Southwest Nigeria. African Journal of Agricultural Research, v. 8, no. 26, p. 3381-3383, 2013.

Illoh, H.C. Foliar epidermis and petiole anatomy of four species of Celosia L. in Nigeria. Feddes Repertorium, v. 106, no. 1/2, p. 15-23, 1995.

Illoh, H. C.; Inyang, U. E. Foliar epidermis and petiole anatomy in some Nigerian Solanum Linn. species in the sub-genus Leptostemon (Bitt) Dun. Glimpses in Plant Research, v. 12, p. 73-86, 1998.

Irvine, F. R. Woody plants of Ghana with a special reference to their uses. London: Oxford University Press, 1961.

Jones, S. Forest tree improvement in Ghana. Commonwealth Forestry Review, v. 48, p. 370-376, 1969.

Keay, R. W. J. Trees of Nigerian. Oxford, UK: Clarendon Press, 1989.

Lamb, A. F. A.; Ntima, 0. O. Terminalia ivorensis: Fast growing timber trees of the Lowland Tropics. Oxford, UK: Commonwealth Forestry Institute, 1971.

Lebrun, J.- P.; Stork, A. Énumération des plantes à fleurs d'Afrique tropicale. 1Généralités et Annonaceae à Pandaceae. Genève: Conservatoire et Jardin Botaniques de la Ville de Genève, 1991.

Lemmens, R. H. M. J.; Wulijarni-Soetjipto, N. Plant resources of South-East Asia. Dye and tannin-producing plants. Wageningen: Pudoc, 1991.

Lemmens, R. H. M. J.; Soerianegara, I.; Wong, W. C. Plant resources of South-East Asia. Timber trees: minor commercial timbers. Leiden: Backhuys Publishers, 1995.

McGaw, L. J.; Rabe, T.; Sparg, S. G.; Jäger, A. K.; Eliff, J. N.; Van Staden, J. An investigation on the biological activity of Combretum spp. Journal of Ethnopharmacology, v. 75, p. 45-50, 2001.

Okeke, C. U.; Iroka, C. F.; Izundu, A. I.; Okereke, N. C.; Onwuasoeze, C. I. Comparative systematic leaf and petiole anatomical studies on the genus Stachytarpheta found in Awka. Nigerian Journal of Medicinal Plant Studies, v. 3, p. 82-88, 2015.

Rodríguez, H. G.; Maiti, R.; Kumari, A. Research advances on leaf and wood anatomy of woody species of a Tamaulipan thorn scrub forest and its significance in taxonomy and drought resistance. Forest 
Research, 5:3, 2016. https://doi.org/ 10.4172/2168-9776.1000183

Schmidt, E.; Lötter, M.; McCleland, W. Trees and shrubs of the Mpumalanga and Kruger National Park. Johannesburg: Jacana Publisher, 2002.

Smith, N.; Scott, A. M.; Henderson, A.; Stevenson, D. W.; Scott, V. H. Flowering plants of the tropics. Princeton, New Jersey: Princeton University Press, 2004.
Veenendaal, E. M.; Swaine, M. D.; Lecha, R. T.; Walsh, M. F.; Abebrese, J. K.; Owusa-Afryie, K. Responses of West African forest seedlings to irradiance and soil fertility. Functional Ecology, v. 10, p. 501-511, 1996.

White, F. The AETFAT chorological classification of Africa: History, methods and amplifications. Bulletin du Jardin Botanique National de Belgique, v. 62, p. 225-281, 1983. 